\title{
Regional Disparities and Government Quality: Redistributive Conflict Crowds out Good Government
}

\author{
Andreas P. Kyriacou* \\ Departament d'Economia, Universitat de Girona, Campus de Montilivi, 17071, Girona; \\ e-mail: andreas.kyriacou@udg.edu
}

\section{Oriol Roca-Sagalés}

Departament d'Economia Aplicada, Universitat Autònoma de Barcelona, Edifici B, Bellaterra 08193, Barcelona; e-mail: oriol.roca@uab.cat

"Las tensiones entre el centro y la periferia continuarán ocupando una parte significativa de la energía política española, lo que distrae al Gobierno de problemas más importantes como la precariedad de la economía".

Tensions between the center and periphery will continue to occupy a significant part of Spanish political energies, which distracts the government from more important problems like the precariousness of the economy"

Eduardo Aguirre, US ambassador in Madrid Source: Wikileaks as reported in El Pais 19/12/2010

\begin{abstract}
High degrees of regional disparities are likely to be associated with distributional conflicts since relatively wealthy regions will tend to resist net outflows of resources while relatively poor ones will call for greater inter-regional redistribution of resources. In this paper, we argue and provide empirical evidence to support the claim that higher income differences across regions increase the salience of inter-regional redistribution, and as a result, crowd out policies aiming towards improvements in government quality or efficiency. Moreover, we explain and show that government quality suffers when regional disparities are combined with political decentralization or territorially segregated ethnic or linguistic groups, while the presence of shared rule, such that the central and sub-central governments jointly decide policies at the national level, tends to mitigate the negative impact of regional disparities on the quality of government.
\end{abstract}

Key words: Government quality, regional disparities, political decentralization, ethnic segregation, shared rule.

\footnotetext{
* Corresponding author. Tel.: + 34972 418716; fax: + 34972 418032. The authors would like to thank financial support from projects ECO2010-21668-C03-02 (Ministerio de Ciencia y Tecnología), 2009SGR-2013 and XREPP (Direcció General de Recerca), as well as a research grant from the Instituto de Estudios Fiscales. This paper benefited from a research stay by the authors at the School of Social Sciences (Economics), Brunel University.
} 


\section{Introduction}

Geography matters for institutional quality. Engerman and Sokoloff (1997, 2000, 2002) attribute the differential institutional development in the New World to differences in geographic or climatic conditions as well as factor endowments. Climatic conditions and low population densities favored agriculture by small family-sized farms in North America, leading to a relatively equal distribution of human capital and wealth. This, in turn led, over time, to more democratic political institutions, more investment in public goods and infrastructure, and to institutions that offered relatively broad access to economic opportunities. Alternatively, in colonies with higher population densities which moreover enjoyed climate and soil conditions well suited for growing labor intensive agriculture, high socio-economic inequalities emerged and these where eventually institutionalized in the guise of formal restrictions of economic opportunities to an elite. Acemoglu et al $(2001 ; 2002 ; 2005)$ argue that in places with high indigenous population densities where in addition the disease environment was not favorable to mass European settlement, the emergence of the extractive state (little protection for private property and limited checks and balances against government expropriation) was more likely. Geographic factors have also been linked to the quality of government in more contemporary settings. A number of studies have explained that the abundance of natural resources creates opportunities for rent seeking behavior and, ultimately, corrupts government (Ades and Di Tella, 1999; Leite and Wiedemann, 2002; Bhattacharyya and Hodler, 2010). Corruption also tends to increase with a country's distance to the world's major trading centers, something attributed to reduced competitive pressures due to higher transport costs (Ades and Di Tella, ibid; Wei, 2000).

In this paper we propose a link between government quality and another geographic variable namely, regional income differences within countries. In particular we consider the extent to which regional disparities within countries can affect the quality of government broadly defined as the extent to which the public sector does not distort the proper functioning of the private sector and is an efficient administrator and provider of public goods (La Porta, et al, 1999). We argue that regional disparities are likely to engender conflicts over the territorial distribution of resources. In line with our opening citation, we argue that inter-regional redistributive conflict is likely to crowd out policies aiming towards improvements in government quality. We identify two mechanisms which are likely to amplify redistributive conflict over resources namely, political decentralization and ethnic or linguistic segregation. Alternatively, the existence of power sharing or shared rule whereby central and sub-central governments co-decide policies at the national level is expected to reduce inter-regional redistributive conflict to the benefit of government quality.

Our empirical analysis, drawn from a sample of 22 OECD countries over the period from 1996 to 2006, provides strong support for our basic intuition that regional disparities-cum redistributive conflict reduces government quality. Government quality is further reduced when regional disparities are framed by political decentralization or in the presence of territorially separated ethnic or linguistic groups. On the other hand, in countries with a degree of shared rule, we find that the negative effect of regional disparities on the quality of government is reduced. Our results are robust to the use of different indicators of government quality, as well as different measures of regional inequalities. 
The paper is structured as follows. In section 2 we review previous theoretical and empirical work which has focused on the relationship between regional inequalities and inter-regional political conflict. We then, in section 3, present our basic intuition and develop our main hypotheses. In section 4 we describe both our key data and variables and our empirical methodology. We present and discuss our results on the relationship between regional disparities and government quality in section 5 before concluding the paper with the main findings.

\section{Regional inequalities and inter-regional conflict}

A growing, mostly theoretical, positive political economy literature has dealt with the causes and consequences of inter-regional redistributive conflict (see Spolaore, 2008 for a review). Early on, Buchanan and Faith (1987) argue that minority regions that are fiscally exploited by majorities have an incentive to secede and provide their own public goods. Importantly, this possibility is seen to impose a limit on the potentially exploitative behavior of the dominant coalition. Alesina and Spolaore (1997; 2003) argue that the majority may go some way towards inducing the minority region to abandon secession by way of a favorable fiscal treatment, but recognize that the majority may then renege on its promises once the region "settles in". ${ }^{1}$ Faced with such a prospect, minorities whose preferences diverge from those of the decisive majority, have an incentive to secede and create their own nation. The authors argue that one realistic way to overcome this credibility problem is by way of suitable "institutional structures to ensure commitment" and to this effect they point to the equality of representation of states in the US Senate, as well as unanimous decision making for constitutional decisions in the EU. ${ }^{2}$

Persson and Tabellini (1996) analyze the role of alternative collective choice mechanisms on inter-regional redistribution. They find that a federation or country-wide vote will tend to oversupply regional transfers in the context of regional-risk sharing, basically because such transfers are less transparent and such a mechanism allows for cross-regional coalitions of voters to emerge. Alternatively, if the public choice mechanism is inter-regional bargaining, conflict is likely to emerge because of the conflicting interest of rich and poor regions and because such a system makes interregional redistribution more transparent. Residents in rich regions would tend to prefer inter-regional bargaining while those from poor regions prefer country-wide voting.

Bolton and Roland (1997) focus on regional conflicts over fiscal policy arising from differences in income distributions across regions. A region with low income inequality may want to secede from a nation with high inequality (and thus a median voter who prefers more redistribution) to avoid higher taxes. Conversely, a region with higher income inequality than the nation may want to break away so as to impose higher taxes and, ultimately, more redistribution. Their theoretical analysis accounts for cases

\footnotetext{
${ }^{1}$ Empirical support for the assertion that secession threats elicit greater funding from the central government has emerged from the experience of the post-Soviet Union (see, Treisman 1996, 1998). Lecours and Béland (2010) explain how federal governments in Canada have, at times, used transfers strategically as a way to deactivate political support for separatist parties in Quebec.

${ }^{2}$ Consistent with this, Kyriacou (2009) provides evidence of more inclusive rules for deciding on the allocation of competencies among the different levels of government in democratic states with territorially concentrated ethnic groups.
} 
where a rich region threatens to secede so as to stop paying transfers to poor regions as well as the case of poor regions that may similarly do so unless more redistribution is adopted across the country.

From a comparative politics perspective, Wibbels (2005) relates regional inequalities to key constitutional moments. In the spirit of Meltzer and Richard $(1981)^{3}$, he argues that in a society where regional median income is substantially below regional mean income, regional representatives from poor regions voting in a constitutional convention have an incentive to vote for political institutions that enshrine the principle of inter-regional redistribution and that give them a voice when national redistributive policy is being decided (including a powerful Senate or super-majority legislative requirements). The resultant institutions will then interact with underlying regional inequalities to frame inter-redistributive regional politics in the post-constitutional period. $^{4}$

Rodden (2009) similarly ascribes the origin of institutional features such as presidentialism or a territory-based upper chamber to the original federal contract but argues that this was due to coalitions between wealthy regions and small poor ones to the detriment of poor large ones. These institutional structures have consequently acted as a break on highly progressive inter-regional redistribution schemes in countries like Argentina, Brazil, and the United States. Where these institutional structures are lacking and, especially in the context of parliamentary systems which favor the emergence of cohesive national parties, a low-income coalition has been able to lock in a system of redistributive transfers as in Canada and Spain as well as many centralized states. This in return has lead to calls from wealthy regions for fiscal decentralization and less transfers or even secession.

A related empirical literature has examined the extent to which interregional income inequality has contributed towards non-violent protest, violent intra-state conflict or secessionism. ${ }^{5}$ Bakke and Wibbels (2006) study ethnic conflict in federal states and provide evidence which supports their argument that high levels of interregional inequality are likely to be politicized leading to sharp inter-regional conflicts about the distribution of resources. Sorens $(2005$; 2008) presents empirical evidence based on regional level data to support the intuition that relatively wealthier regions are more likely to produce secessionist political movements since they experience net outflows of resources in the context of inter-regional redistribution.

More in the spirit of Bolton and Roland (1997), Sambanis and Milanovic (2009) argue that high within-region income inequality may either hamper the demand for sovereignty (because the expected costs and benefits are likely to accrue unevenly between rich and poor) or increase it (by allowing elites to tap into class cleavages). Their empirical evidence using regional level data is more in line with the latter explanation. Similarly, Ostby et al (2009) find that high levels of intra-regional socioeconomic inequalities are positively associated with civil conflict in a sample of countries from Sub-Saharan Africa.

\footnotetext{
${ }^{3}$ Redistribution emerges because the decisive median voter is poor relative to the mean, and thus benefits from a progressive tax/transfers scheme.

${ }^{4}$ Wibbels (2005) illustrates his argument by referring to the constitutional moments of Argentina, the U.S and India. Kyriacou (2000) discusses just such a dynamic in the context of the constitutional negotiations aiming to resolve the long-standing Cyprus conflict.

${ }^{5}$ Stewart (2003) has proposed "horizontal inequality" or inequality between groups as a factor contributing towards violent conflict (See Stewart, 2008 for an extensive treatment).
} 


\section{Inter-regional redistributive conflict and government quality}

This non-exhaustive review of the literature brings home the point that high degrees of regional disparities are likely to be associated with distributional conflicts since relatively wealthy regions will tend to resist net outflows of resources while relatively poor ones will call for greater inter-regional redistribution of resources. Perhaps less obviously, our basic point here is that the increasing salience of inter-regional redistribution in the context of high income inequalities is likely to focus attention away from other policy areas, most notably, policies aiming towards improvements in government quality or efficiency.

Our argument is simple. Politicians facing an electoral constraint can improve their electoral prospects by either entering the redistributive game or by improving government efficiency. Policies aiming to improve the quality of government are likely to be resisted by public sector interest groups with a stake in the status quo. This has been clearly explained by the literature on the political economy of reform (see Tomassi and Velasco, 1996 and Rodrick, 1996 for reviews) and in particular by work focusing on institutional or public sector reforms (for example, Navia and Velasco, 2003). As these last authors state:

"[T] he set of interests potentially affected [by public sector reforms] reads like a Who's Who of highly organized and vocal groups: teachers' and judicial unions, the upper echelons of the public bureaucracy, state and local governments, owners and managers of private monopolies, and the medical establishment..." (Navia and Velasco, 2003, p.268).

No comparable interest group opposition is likely to be met by governments entering the redistributive game. Indeed, electoral entrepreneurs who enter the redistributive game are likely to find support from interest groups with a stake in the status quo. Moreover, voters will tend to be more responsive to redistributive politics the greater the regional disparities. The combination of these factors means that redistributive politics may be a much more attractive strategy for politicians than institutional reform. ${ }^{6}$ This leads us to our first hypothesis:

H1. Regional inequalities should increase the salience of inter-regional redistributive politics something which, ultimately, should reduce government quality.

This argument is especially relevant for politicians standing for election at the regional level or, in other words, in the context of political decentralization. In itself, political decentralization in the form of sub-national elections empowers voters and so is likely to improve government quality (Seabright, 1996), but it may also lead to the capture of sub-national politicians by special interests thereby having the opposite effect (Bardhan, 2002; Prud'homme, 1995). More pertinent for our argument, a large literature in political science has debated on whether political decentralization increases or reduces

\footnotetext{
${ }^{6}$ Our argument here is in the spirit of Buchanan and Congleton (1998) who argue that in the absence of suitably designed institutions even well meaning politicians are drawn into redistributive politics to the detriment of public good considerations.
} 
political conflict. ${ }^{7}$ The presence of political decentralization may lead to a reduction of political conflict insofar as it grants distinct regions or groups control over their affairs. Alternatively, political decentralization may also increase conflict insofar as it opens the way for regionalist/secessionist political parties (Brancati, 2006, 2007). Such parties are likely to gravitate around redistributive grievances, the more so the higher the regional inequalities. Regionally elected politicians from relatively poor or wealthy regions will be tempted by the politics of territorial redistribution to the detriment of improvements in government quality. One scholar of political conflict over inter-provincial transfers in Canada puts it as follows,

"[For provincial politicians] it is far easier and more convenient to attribute the deficiencies of one's highways, hospitals, universities or schools to the distant federal government, which is generally inhibited by constitutional propriety and self-respect, from responding to the verbal abuse that is thrown in its direction, than it is to repair the deficiencies. Blaming other provincial governments is more hazardous, since they are more likely to take offence, and since their cooperation may be required subsequently in the endless battle to win concessions from "Ottawa". However, even that may be more convenient than admitting that the source of the province's problems might lie within its own borders, or even within the walls of its legislature. '(Stevenson, 2007, p.2).

This train of thought yields the following testable hypothesis:

$\mathrm{H} 2$. The combination of regional disparities and political decentralization should reduce government quality.

Redistributive politics, and thus the negative effect on government quality, is likely to be more intense in the presence of geographically concentrated ethnic or linguistic groups. Abstracting for the moment from whether ethnic groups live separately or not, the presence of distinct groups means that political entrepreneurs have an incentive to "play the ethnic card". Ethnic hostilities are a successful device for abstracting the populace from seeing the extensiveness of government failure (Hardin, 1995; Miquel, 2007) and ethnic voting implies that politicians may be chosen because of their ethnicity rather than competence (Banerjee and Pande, 2007). Politicians may even seek to increase their degrees of freedom by resorting to a 'top down' legitimization of their acts, that is, by arguing that beyond being accountable to the interests of their fellow group members, they are accountable to history itself (Wintrobe, 1995)..$^{8}$

These dynamics are likely to be strengthened if ethnic groups are separated geographically. Glaeser (2005) describes how political entrepreneurs facing an election constraint have an incentive to broadcast messages which demonize social groups which differ on one or other potentially salient dimension. Individuals can only verify the veracity of these messages at a private information cost. These costs are likely to be higher if people have no contact with the group being rubbished (they are increasing

\footnotetext{
${ }^{7}$ For recent contributions and reviews see the 2009 special issue of Regional and Federal Studies entitled "The Paradox of Federalism: Does Self-Rule Accommodate or Exacerbate Ethnic Divisions?"

${ }^{8}$ For a detailed discussion of the incentives of political entrepreneurs to mobilize ethnic groups as well as the conditions under which ethnic groups are likely to be responsive to such mobilizing efforts see Kyriacou (2005).
} 
with territorial segregation) while they decline with group contact (decreasing with integration). In other words, ethnic segregation may increase the political gains of playing the ethnic card. Empirical support for this is provided by Alesina and Zhuruvskaya (2011) who find that the share of ethnic parties rises monotonically with ethnic segregation. More importantly for our discussion here, they report that ethnic and linguistic segregation are negatively correlated with government quality and that this correlation is especially strong in democracies indicating the role of elections as a transmission mechanism. An additional (untested) claim by them linking territorial politics with government quality is that inasmuch as geographical segregation facilitates secessionism, this may put pressure on the central government to spend resources on repression or appeasement of secessionist territories to the detriment of spending on productive public goods and good governance generally.

The incentive to play the redistributive game will increase even further in the presence of both ethnic or linguistic segregation and regional disparities, to the detriment of government quality. Now the redistributive conflict will also acquire an ethnic dimension and as such, it is likely to be more intense. Liesbet Hooghe (2004) notes how in Belgium, language has always been a socio-economic marker. French speakers in the Walloon regions where relatively wealthy up to the 1950 s but deindustrialization there and industrial modernization in the Dutch speaking Flemish region, meant that fortunes where reversed in the second half of the $20^{\text {th }}$ century. This provides the backdrop against which both redistributive and secessionist conflict has played out over the years. Lecours and Béland (2010) explain how intergovernmental relations in Canada have been conditioned by strong provincial identities, especially in Quebec and Newfoundland. Tension between net contributors and net receivers have described Spanish inter-governmental relations since the creation of the Estado de Autonomías (state of autonomies) in the late $70 \mathrm{~s}$, with strong resistance towards net outflows coming from relatively wealthy and linguistically distinct Catalonia. Bakke and Wibbels (2006) provide empirical evidence which supports the idea that when regional disparities overlap with regionally concentrated ethnic groups, this intensifies conflict even further because of the relative facility of ethnic regional elites (compared to non-ethnic ones) to mobilize demands for a bigger slice of the pie. ${ }^{9}$ This discussion leads us to our third hypothesis:

H3. Regional inequalities combined with ethnic segregation should reduce government quality.

Territorial redistributive politics does not occur in an institutional vacuum. Because conflict over the distribution of resources is likely to play out at the national level, it is important to consider the influence of national level institutions. One way to approach this issue is by examining the existence of institutionalized veto points which provide regional governments with leverage over national politics, including decisions on intergovernmental redistribution. A case in point is the presence of a bicameral system whose second chamber can block lower house legislation and whose representatives are elected or appointed on a regional basis. Veto points represent the notion of shared rule whereby central and sub-central governments jointly decide policies at the national level (Rodden, 2004).

\footnotetext{
${ }^{9}$ Similarly, Sambanis and Milanovic (2009) find that the combination of higher intra-regional income inequalities and ethnic separation increases demands for sovereignty.
} 
All else equal, the presence of more veto points can protect against bad government, but it may also prevent improvements in government effectiveness by locking in the status quo (Panizza 2001; Treisman 2002; Kyriacou and Roca-Sagalés 2011a). For our purposes, to the extent that veto points empower regional governments, they may act as a conduit through which redistributive conflict moves up to the national level, to the detriment of good government. Alternatively, by giving sub-national politicians a say when redistributive decisions are being taken, shared rule can help manage political conflict. Shared rule can act as a "commitment" device - in the sense of Alesina and Spolaore (2003), - and as such it can help reduce secessionism. More generally, shared rule is a form of power sharing which has mostly been seen in a favorable light as an instrument for conflict management, precisely because it requires ethnic minority acquiescence for decisions to be taken at the national level (Lijphart, 1984). Support for the conflict-abating effect of shared rule is provided by Brown (2009) who finds that it unambiguously reduced ethno-regional protest in a panel of more than 20 countries over the period from 1985 and 2003. To the extent that shared rule can reduce political conflict deriving from regional inequalities, this should help crowd-in good government. In light of this empirical evidence, we would expect that:

H4. Shared rule should mitigate the negative impact of regional disparities on government quality.

\section{Data and empirical approach}

To measure government quality we use two sources which provide cross country data which is, moreover, comparable across time. The first source is the Worldwide Governance Indicators (WGI) project published by the World Bank (Kaufmann et al, 2006). These indicators are based on several hundred individual variables from thirtyone data sources measuring perceptions of governance. We use weighted averages of the underlying data, with weights reflecting the precision of the individual data sources. We are interested in four indicators capturing good governance namely, control of corruption, rule of law, regulatory quality and government effectiveness. ${ }^{10}$ Our dependent variable is the average of all these dimensions, in line with our concern about the factors affecting overall government performance as well as empirical evidence suggesting that the individual indicators are all measuring the same broad concept (Langbein and Knack, 2010). The aggregate indicator varies from minus to plus 2.5 and higher values represent higher government quality across these dimensions. Another source is the International Country Risk Guide (ICRG) as developed by the Political Risk Services Group to assess the political, economic and financial risks across

\footnotetext{
${ }^{10}$ Control of corruption measures the extent to which public power is exercised for private gain, including both petty and grand forms of corruption, as well as capture of the state by elites and private interests. Rule of law considers the extent to which agents have confidence in and abide by the rules of society, and in particular the quality of contract enforcement, the police, and the courts, as well as the likelihood of crime and violence. Regulatory quality reflects on the ability of the government to formulate and implement sound policies and regulations that permit and promote private sector development. Government effectiveness measures the quality of public services, the quality of the civil service and the degree of its independence from political pressures, the quality of policy formulation and implementation, and the credibility of government commitment to such policies.
} 
countries. The index is based on the analysis of a worldwide network of experts, and is subject to a peer review process to ensure the coherence and comparability across countries. To facilitate comparability with the World Governance Indicators, we focus on three dimensions from this source namely corruption, rule of law and bureaucratic quality. Again, the quality of government indicator used here is the average of these three dimensions where a higher number implies higher government quality. In our sample, government quality is highest in the Scandinavian countries and lowest in the Eastern European countries and Mexico (see table 1 for the summary statistics of all the variables).

Table 1. Summary statistics.

\begin{tabular}{lccccc}
\hline & Mean & Maximum & Minimum & Std, Dev, & No. Obs. \\
\hline Governement Quality- WGI & 1.4838 & 2.1099 & -0.0776 & 0.5129 & 212 \\
Governement Quality - ICRG & 4.5250 & 5.3333 & 2.3333 & 0.6850 & 212 \\
Regional Disparities (a) & 0.2340 & 0.6035 & 0.0506 & 0.1083 & 212 \\
Regional Disparities (b) & 0.2131 & 0.5076 & 0.0520 & 0.0834 & 212 \\
Regional Disparities (c) & 0.0281 & 0.1426 & 0.0013 & 0.0241 & 212 \\
Regional Disparities (d) & 0.2569 & 0.6774 & 0.0777 & 0.1377 & 212 \\
Regional Disparities (e) & 0.3385 & 0.7830 & 0.0630 & 0.1495 & 107 \\
Political Desc. - Schneider & 0.7120 & 1.0000 & 0.2900 & 0.2013 & 212 \\
Political Desc. - DPI & 1.4660 & 2.0000 & 0.0000 & 0.7367 & 220 \\
Ethnic Segregation & 0.0418 & 0.2440 & 0.0010 & 0.0669 & 212 \\
Language Segregation & 0.0717 & 0.2440 & 0.0010 & 0.0743 & 172 \\
Shared Rule & 2.6126 & 9.0000 & 0.0000 & 3.0172 & 207 \\
Law Making & 0.5995 & 2.0000 & 0.0000 & 0.7657 & 207 \\
Executive Control & 0.5471 & 2.0000 & 0.0000 & 0.7309 & 207 \\
Fiscal Control & 0.5947 & 2.0000 & 0.0000 & 0.7680 & 207 \\
Constitutional Reform & 0.9350 & 3.0000 & 0.0000 & 1.2111 & 207 \\
GDP & 26.891 & 45.694 & 8.697 & 7.823 & 212 \\
Governement Size & 45.65 & 65.30 & 21.89 & 7.69 & 212 \\
Fiscal Descentralization & 34.23 & 63.36 & 5.14 & 13.48 & 212 \\
\hline
\end{tabular}

We measure regional disparities in several ways since different inequality indices entail changes in value judgements on income differences at the tails of the distribution leading to different inequality orderings (Lambert, 2001; Cowell, 1995). First, we use the population-weighted coefficient of variation (PW-CV), which is independent of the scale, population size and number of regions considered and satisfies the Pigou-Dalton principle (Cowell, 1995). The PW-CV is the population-weighted standard deviation of GDP per capita level within a country, divided by the country's GDP per capital level:

$\mathrm{PW}-\mathrm{CV}=\frac{1}{\bar{y}}\left[\sum_{i=1}^{n} p_{i}\left(\bar{y}-y_{i}\right)^{2}\right]^{1 / 2}$ 
where $\bar{y}$ is the average country GDP per capita, $y_{i}$ and $p_{i}$ are the GDP per capita and population share of the region, and $\mathrm{n}$ is the number of regions. The PW-CV basically depicts disparities among the regions of a country, taking into consideration their relative population weights and takes values between 0 (equality) and 1 (maximum disparities).

Another measure is the population-weighted standard deviation of the logarithm of regional GDP per capita (PW-LOG), which is a measure widely used in the convergence literature to capture sigma convergence (Barro and Sala-i-Martin 1995):

PW-LOG $=\left[\sum_{i=1}^{n} p_{i}\left(\ln \bar{y}-\ln y_{i}\right)^{2}\right]^{1 / 2}$

where $\bar{y}$ is the country GDP per capita average, $y_{i}$ and $p_{i}$ are the GDP per capita and population share of the region, and $n$ is the number of regions.

Third, we consider a measure proposed by Theil (1967) that is typically employed in the inequality literature and has also been used in order to analyse spatial disparities (Azzoni, 2001; Novotny, 2007):

THEIL $=\left[\sum_{i=1}^{n} p_{i} \ln \left(\frac{\bar{y}}{y_{i}}\right)\right]$

Fourth, a coefficient of variation of the regional GDP per capita indicator (CV) that does not take into account the distribution of the population across all regions. Certainly, in countries where a relatively larger share of the population lives in the main region or is concentrated in some specific areas, output might also be concentrated in these areas. In this sense, this indicator would present higher disparities - compared to PW-CV - when the main region is significantly larger in terms of population than the others (that would be the case where the population is concentrated in the region's capital, but also because of the existence of large hubs concentrated in some regions).

$\mathrm{CV}=\frac{1}{\bar{y}}\left[\frac{1}{n} \sum_{i=1}^{n}\left(\bar{y}-y_{i}\right)^{2}\right]^{1 / 2}$

Finally we also test our hypotheses by way of a population weighted coefficient of variation (PW-CV-UNEMP) capturing the dispersion of unemployment rates, by NUTS 2 regions in the European Union. Although using this variable implies reducing our sample size, it has the advantage that it is scarcely correlated with the other regional disparity measures employed. ${ }^{11}$

According to our first three indicators, regional disparities are highest in Slovakia and especially Mexico while they are lowest in the Netherlands and Australia. With our un-weighted measure, regional disparities are highest in Slovakia and

\footnotetext{
${ }^{11}$ The simple correlations of all our regional disparity variables bar the one based on regional unemployment rates range from 0.80 to 0.96 , while the correlation between PW-CV-UNEMP and the rest ranges from 0.22 and 0.37 .
} 
Belgium. Things change even more when we take the regional unemployment indicator. Now Italy and Germany have the greatest regional disparities while Norway and Netherlands have the lowest.

Having identified our measures of the main variables, we can now begin to consider if greater regional disparities are associated with lower government quality. Although not accounting for the influence of omitted variables, a simple plot (Figure 1) of government quality (WGI) on regional disparities (PW-CV) reveals the expected negative relationship. A look at the simple correlation between these variables confirms this, since the corresponding correlation coefficient is 0.667 with a p-value of zero. The plot also reveals no outliers something which would indicate that the regression results presented in the paper are not being driven by any specific country.

Figure 1. Government quality and regional disparities (average values for the period 1996-2006)

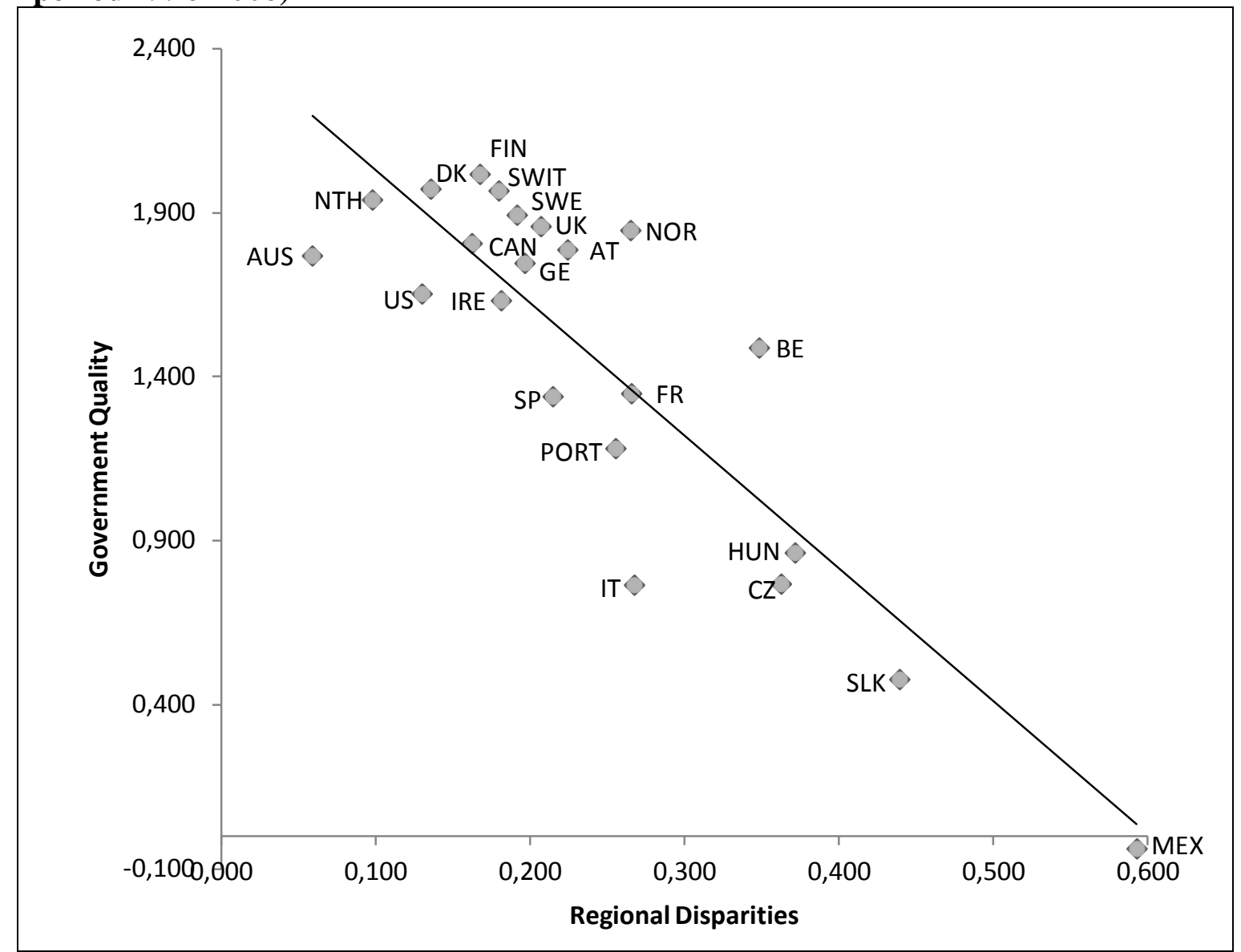

We draw from Schneider (2003) to measure political decentralization. His variable captures the notion that, in politically decentralized systems, citizens define interests and form identities on the basis of local concerns, and organizations such as parties and social movements operate locally and compete over local issues and in local elections. Because both preference aggregation and political competition occur in the context of electoral politics, he uses confirmatory factor analysis based on the existence of elections at the municipal or state/provincial levels in 1996 to generate an index between 0 and 1, with higher values representing more political decentralization (see also Rodríguez-Pose and Ezcurra, 2010). In our data, the most politically decentralized 
countries are Slovakia and Mexico and Italy and the least are Finland and Portugal. As a robustness check we also employ the variable STATE from the Data base of Political Institutions, which takes the value of 0 if neither the state/provincial executive nor the legislature are locally elected, 1 if the executive is appointed by the legislature is elected, and 2 if both are elected on a sub-national basis (Beck et al, 2001).

To account for the territorial separation of ethnic or linguistic groups we use an indicator of segregation from Alesina and Zhuravskaya (2011). This is a continuous variable which ranges from a value of 1 , if a country's regions are inhabited by different ethnic or linguistic groups (and therefore each region is fully homogeneous), and a value of 0 if each region has the same ethnic or linguistic composition as the country as a whole. This indicator is, in fact, a squared coefficient of variation and it gives higher weight to the deviation of group composition from the national average in more populous regions than in less populous ones. Scaling by the total number of groups keeps the index between 0 and 1. Ethnic and linguistic segregation is highest in Spain and Belgium and lowest in Germany, the Netherlands and Sweden.

Finally, we turn to our measure of shared rule which comes from Hooghe et al (2008) and which reflects the authority exercised by a regional government or its representatives in the country as a whole. This indicator is composed of 4 components called, law making, executive control, fiscal control and constitutional reform which capture respectively, the extent to which regional representatives co-determine national legislation, national policy in inter-governmental meetings, the distribution of national tax revenues and constitutional change. In our sample, the aggregate indicator ranges from 0 to 9 with the lower value assigned to unitary states (for example from Scandinavia and Eastern Europe) while higher values correspond to federal states (e.g. Australia, Belgium and Germany).

We employ a Feasible General Least Squares (FGLS) estimator. This is asymptotically more efficient than the pooled OLS estimator when the series exhibit heteroskedasticity (Wooldridge 2006, p. 292). We use period SUR weights (Seemingly Unrelated Regression) that corrects for both period heteroskedasticity and serial correlation within a given cross-section (Parks, 1967). Neither fixed nor random effects models are appropriate. Fixed effects models rely exclusively on the time variation within each cross-section unit, something which is limited in our key variables (government quality and regional inequality). Country fixed effects are also inappropriate since we want to calibrate the impact of time constant variables (political decentralization and ethnic segregation). In the case of random effects, it would imply that our sample is a random one from a large population, something which obviously is not the case since our cross-section units are a group of (higher income and democratic) OECD countries (Hsiao, 2003).

We estimate the following model:

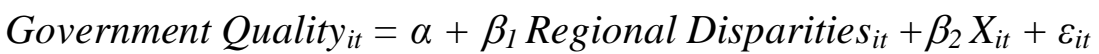

where $i$ refers to countries, $t$ to years, $\alpha$ is a constant, $X_{i t}$ is a vector of control variables (GDP per capita, the size of the public sector, fiscal decentralization, transition economy) and $\varepsilon_{i t}$ is the error term. Our choice of control variables is guided by the need to account for factors which may affect both regional disparities (and thus territorial redistributive conflict) and government quality and, consequently, whose omission might bias the estimated impact of regional disparities on government quality.

Richer countries tend to have better government quality since economic development makes better quality institutions more affordable (Islam and Montenegro, 
2002), and will tend to create a demand for better government (La Porta, et al. 1999), perhaps because of income's positive effect on education, literacy and depersonalized relationships (Treisman, 2000). Wealthier countries are also likely to have a greater scope for redistributive policies aimed at reducing regional disparities (Lessmann, 2009). Similarly, countries with larger public sectors may be better endowed to address regional inequalities (Rodríguez-Pose and Ezcurra, 2010). A bigger public sector implies greater corruption due to the greater possibility for rents (Tanzi 1998). On the other hand, a larger public sector could mean that governments are better endowed with resources thereby potentially improving their performance. ${ }^{12}$

Fiscal decentralization can improve government quality by putting resources in the hands of better informed benevolent local governments (Oates, 1972), or by promoting inter-jurisdictional competition for fiscal resources, thus making sub-central governments more responsive to citizens' preferences (Brennan and Buchanan, 1980). Because fiscal decentralization implies that central government has fewer fiscal resources to apply towards redistribution, it may increase regional disparities (Prud'homme, 1995). Moreover, fiscal decentralization may translate to a reduced influence of poorer regions over the inter-regional allocation of fiscal resources, something which may perpetuate and even enhance existing territorial disparities (Rodríguez-Pose and Ezcurra, 2010). On the other hand, fiscal decentralization may reduce regional disparities insofar as the resultant inter-jurisdictional competition strengthens poorer regions incentives to adopt growth promoting policies (McKinnon, 1997 and Qian and Weingast, 1997). To measure fiscal decentralization we use data from the OECD General Government Accounts, which control for inter-governmental transfers or grants to and from central government respectively (see also Kyriacou and Roca, 2011b).

We further control for whether a country was a member of the Soviet Union. La Porta et al (1999) have argued that a country's legal tradition is an indicator of the power of the state relative to property owners, with common law systems tilting the balance in favor of the latter and socialist law systems favoring the former to the detriment of efficient government. Moreover, the transition from socialism to capitalism may have increased regional disparities because it seems to have benefited capital cities and major urban areas while harming agricultural and manufacturing regions (Petrakos, 2001; Rodríguez-Pose and Ezcurra, 2010).

\section{Empirical results}

Table 2 presents the estimates of our main hypothesis, H1. Before turning to the relationship between regional disparities and government quality a word is in order about the estimated effect of our control variables. Fully in line with both the theoretical priors and previous empirical work, government quality is positively related to GDP per capita and negatively related to the transition from single party rule and central planning to multiparty democracy and the free market. Our results also clearly support the expectation that governments that are better endowed with resources (larger public sectors) are likely to out-perform poorly endowed ones (see also, Montinola and Jackman, 2002).

\footnotetext{
${ }^{12}$ In this respect, higher civil service pay has been found to reduce bureaucratic corruption (Van Rijckeghem and Weder 2001).
} 
Fiscal decentralization tends to improve government quality, a finding which has received wide support in previous work (for example, Fisman and Gatti, 2002; Fan et al, 2009). On the other hand, we find that political decentralization reduces government quality, something which supports the idea that sub-national elections increase the risk of capture by special interests to the detriment of government efficiency. The opposite effects of fiscal decentralization and political decentralization on government quality are also reported by Kyriacou and Roca (2011a).

In line with the results obtained by Alesina and Zhuravkaya (2001), we find that ethnic segregation has a negative impact on government quality. However, our results are less robust than those obtained by them despite the fact that our sample is limited to democratic countries (remember that their findings are strongest in a sub-sample of such countries, indicating the role of elections as a transmission mechanism). One explanation could be the different sample sizes (they have 77 democratic countries). Another could be the fact that they do not control for regional income inequalities, a difference which we will expand on below.

Turning now to the relationship between regional disparities and government quality, table 2 clearly indicates a negative correlation which is robust to the use of different measures of government quality as well as different indicators of regional disparities. This lends a degree of support to Hypothesis 1 such that regional disparitiescum inter-regional redistributive conflict tend to crowd out good government. The results obtained when estimating model 1 show that a significant proportion of the difference in government quality in the countries considered is explained, with adjusted $\mathrm{R}^{2}$ numbers ranging from 0.46 to 0.76 (albeit in the latter case the sample size is restricted to 16 European Union countries).

In a tentative attempt to consider whether the estimated impact of ethnic segregation on government quality reported by Alesina and Zhuravskaya (2011) is plagued by omitted variable bias, we drop our measures of regional disparities from the regressions. Like them, we find that ethnic segregation becomes robustly and negatively associated to government quality. ${ }^{13}$ We take this as indicative of the possibility that Alesina and Zhuraskaya's (2011) robust results might be partly driven by the omission of regional inequality. In other words, ethnic segregation could be picking up the effect of significant income differences across regions on the quality of government in the manner that we propose (Hypothesis 1). Of course, the way to check for this is to control for regional inequalities in their estimates, something which, unfortunately, is not possible because of the absence of good regional disparities data for their sample.

\footnotetext{
${ }^{13}$ Results not shown but are, of course, available upon request.
} 
Table 2. Regional Disparities and Government Quality (H1). Feasible Generalized Least Squares (FGLS).

\begin{tabular}{|c|c|c|c|c|c|c|c|c|c|c|}
\hline $\begin{array}{c}\text { Government Quality } \\
\text { variable } \Rightarrow>\end{array}$ & $\begin{array}{l}\text { (1) } \\
\text { WGI }\end{array}$ & $\begin{array}{c}\text { (2) } \\
\text { ICRG }\end{array}$ & $\begin{array}{l}\text { (3) } \\
\text { WGI }\end{array}$ & $\begin{array}{c}\text { (4) } \\
\text { ICRG }\end{array}$ & $\begin{array}{l}\text { (5) } \\
\text { WGI }\end{array}$ & $\begin{array}{c}\text { (6) } \\
\text { ICRG }\end{array}$ & $\begin{array}{l}\text { (7) } \\
\text { WGI }\end{array}$ & $\begin{array}{c}\text { (8) } \\
\text { ICRG }\end{array}$ & $\begin{array}{l}\text { (9) } \\
\text { WGI }\end{array}$ & $\begin{array}{l}\text { (10) } \\
\text { ICRG }\end{array}$ \\
\hline GDP per capita & $\begin{array}{c}0.692 \\
(0.068)^{* * *}\end{array}$ & $\begin{array}{l}0.103 \\
(0.161)\end{array}$ & $\begin{array}{c}0.673 \\
(0.066)^{* * *}\end{array}$ & $\begin{array}{l}0.137 \\
(0.167)\end{array}$ & $\begin{array}{c}0.577 \\
(0.072)^{\star * *}\end{array}$ & $\begin{array}{l}-0.134 \\
(0.175)\end{array}$ & $\begin{array}{c}0.795 \\
(0.074)^{\star * \star}\end{array}$ & $\begin{array}{c}0.430 \\
(0.153)^{* * *}\end{array}$ & $\begin{array}{c}0.504 \\
(0.197)^{\star *}\end{array}$ & $\begin{array}{l}0.178 \\
(0.345)\end{array}$ \\
\hline Size of Government & $\begin{array}{c}0.834 \\
(0,137)^{\star \star *}\end{array}$ & $\begin{array}{c}1.647 \\
(0,340)^{\star * \star}\end{array}$ & $\begin{array}{c}0.850 \\
(0,138)^{\star * *}\end{array}$ & $\begin{array}{c}1.642 \\
(0,360)^{* * *}\end{array}$ & $\begin{array}{c}0.642 \\
(0,137)^{\star * *}\end{array}$ & $\begin{array}{c}1.298 \\
(0,354)^{\star * *}\end{array}$ & $\begin{array}{c}0.986 \\
(0,162)^{\star * *}\end{array}$ & $\begin{array}{c}1.872 \\
(0,355)^{\star * *}\end{array}$ & $\begin{array}{l}0.015 \\
(0,328)\end{array}$ & $\begin{array}{l}-0.046 \\
(0,499)\end{array}$ \\
\hline Fiscal Decentralization & $\begin{array}{c}0.644 \\
(0,157)^{\star * *}\end{array}$ & $\begin{array}{c}1.049 \\
(0,296)^{* * *}\end{array}$ & $\begin{array}{c}0.702 \\
(0,158)^{* * *}\end{array}$ & $\begin{array}{c}1.182 \\
(0,307)^{\star \star \star}\end{array}$ & $\begin{array}{c}0.695 \\
(0,157)^{\star \star \star}\end{array}$ & $\begin{array}{c}1.373 \\
(0,286)^{\star \star *}\end{array}$ & $\begin{array}{c}0.836 \\
(0,170)^{\star \star \star}\end{array}$ & $\begin{array}{c}1.593 \\
(0,312)^{\star * *}\end{array}$ & $\begin{array}{c}1.344 \\
(0,302)^{\star * \star}\end{array}$ & $\begin{array}{c}1.566 \\
(0,454)^{* * *}\end{array}$ \\
\hline Transition Economies & $\begin{array}{l}-0.261 \\
(0,124)^{\star *}\end{array}$ & $\begin{array}{l}-0.060 \\
(0,144)\end{array}$ & $\begin{array}{l}-0.295 \\
(0,115)^{\star *}\end{array}$ & $\begin{array}{l}-0.214 \\
(0,154)\end{array}$ & $\begin{array}{c}-0.355 \\
(0,115)^{\star * *}\end{array}$ & $\begin{array}{l}-0.314 \\
(0,150)^{\star *}\end{array}$ & $\begin{array}{l}-0.176 \\
(0,137)\end{array}$ & $\begin{array}{l}0.024 \\
(0,175)\end{array}$ & $\begin{array}{c}-0.473 \\
(0,154)^{\star * \star}\end{array}$ & $\begin{array}{c}-0.601 \\
(0,267)^{\star \star}\end{array}$ \\
\hline Political Decentralization & $\begin{array}{l}-0.380 \\
(0,183)^{\star *}\end{array}$ & $\begin{array}{c}-0.531 \\
(0,198)^{* \star *}\end{array}$ & $\begin{array}{l}-0.326 \\
(0,170)^{*}\end{array}$ & $\begin{array}{c}-0.586 \\
(0,215)^{\star \star \star}\end{array}$ & $\begin{array}{c}-0.367 \\
(0,173)^{\star *}\end{array}$ & $\begin{array}{c}-0.574 \\
(0,199)^{\star * *}\end{array}$ & $\begin{array}{c}-0.609 \\
(0,195)^{\star \star \star}\end{array}$ & $\begin{array}{c}-0.852 \\
(0,226)^{* * *}\end{array}$ & $\begin{array}{c}-0.520 \\
(0,165)^{* * *}\end{array}$ & $\begin{array}{c}-0.787 \\
(0,278)^{\star * \star}\end{array}$ \\
\hline Ethnic Segregation & $\begin{array}{l}-0.855 \\
(0.573)\end{array}$ & $\begin{array}{l}-1.155 \\
(0.633)^{*}\end{array}$ & $\begin{array}{l}-0.815 \\
(0.534)\end{array}$ & $\begin{array}{l}-1.500 \\
(0.672)^{\star *}\end{array}$ & $\begin{array}{l}-0.560 \\
(0.540)\end{array}$ & $\begin{array}{l}-1.383 \\
(0.628)^{\star *}\end{array}$ & $\begin{array}{l}-0.423 \\
(0.571)\end{array}$ & $\begin{array}{l}-1.540 \\
(0.750)^{* *}\end{array}$ & $\begin{array}{l}-0.614 \\
(0.505)\end{array}$ & $\begin{array}{l}-2.078 \\
(0,852)^{\star *}\end{array}$ \\
\hline Regional Disparities (A) & $\begin{array}{l}-1.094 \\
(0.174)^{* * *}\end{array}$ & $\begin{array}{l}-2.915 \\
(0.457)^{\star \star *}\end{array}$ & & & & & & & & \\
\hline Regional Disparities (B) & & & $\begin{array}{l}-1.466 \\
(0.211)^{\star \star *}\end{array}$ & $\begin{array}{l}-3.136 \\
(0.574)^{\star * \star}\end{array}$ & & & & & & \\
\hline Regional Disparities (C) & & & & & $\begin{array}{l}-5.388 \\
(0.713)^{* * *}\end{array}$ & $\begin{array}{l}-12.596 \\
(1.906)^{\star * *}\end{array}$ & & & & \\
\hline Regional Disparities (D) & & & & & & & $\begin{array}{l}-0.506 \\
(0.192)^{\star \star *}\end{array}$ & $\begin{array}{l}-1.140 \\
(0.384)^{\star * *}\end{array}$ & & \\
\hline Regional Disparities (E) & & & & & & & & & $\begin{array}{l}-0.331 \\
(0.136)^{\star *}\end{array}$ & $\begin{array}{l}-1.062 \\
(0.023)^{* * *}\end{array}$ \\
\hline Adjusted $\mathrm{R}^{2}$ & 0.60 & 0.54 & 0.62 & 0.54 & 0.58 & 0.54 & 0.50 & 0.46 & 0.76 & 0.55 \\
\hline Number of countries & 22 & 22 & 22 & 22 & 22 & 22 & 22 & 22 & 16 & 16 \\
\hline Observations & 212 & 212 & 212 & 212 & 212 & 212 & 212 & 212 & 107 & 107 \\
\hline
\end{tabular}

Standard Errors in parentheses. * ${ }^{* *}, * * *$ measures statistical significance at the 10,5 and $1 \%$ levels respectively. WGI refers to the World Governance Indicators and ICRG to the International Country Risk Guide. A is PW-CV; B is PW-LOG; C is THEIL; D is CV and E is PW-CV-UNEMP. All these variables are fully defined in the text. "Political Decentralization" and "Ethnic segregation" are time constant variables. All regressions report FGLS using Period SUR weights. 
Table 3 reports our regression results in relation to Hypotheses 2, 3 and 4. The first two columns reveal the influence of political decentralization on the relationship between regional disparities and government quality (Hypothesis 2). As expected, the combination of regional disparities and regional elections reduces government quality, pointing to the idea that the latter amplifies inter-governmental redistributive conflict. The results are maintained regardless of the way we measure political decentralization.

Columns 3 and 4 report our findings on the influence of ethnic or linguistic segregation. The interaction with regional disparities is negative indicating that segregation, like political decentralization, amplifies redistributive conflict and crowds out good government (Hypothesis 3). From another perspective, our results also suggest that the negative impact of ethnic or linguistic segregation on government quality is mediated by the severity of regional disparities. At low disparity levels - below 0.22 or 0.17 depending on whether we take the results in columns 3 and 4 respectively, - ethnic or linguistic segregation does not necessarily reduce government quality. Above these levels, it is unambiguously pernicious for the quality of government.

The remaining columns report our estimates of the impact of shared rule on government efficiency. We show the estimates using the aggregate indicator of shared rule, but also employing its four constituent components as a robustness check (simple correlations range from 0.54 between Executive Control and Constitutional Reform and 0.90 between the Aggregate measure and Law Making). Our results indicate that the presence of shared rule mitigates the estimated negative impact of regional disparities on government quality in line with Hypothesis 4. This suggests that shared rule acts as a conflict management instrument - as previously reported by Brown (2009) - and as a corollary has the salutary effect of crowding-in good government.

Before closing, we address an additional concern namely reverse causality. Institutional quality has been identified as an important factor explaining economic development at the country level (Acemoglu et al, 2005; Rodrik et al, 2004). Could it be that government quality also affects regional disparities? We think that this may be the case, but that the nature of the causal relationship should not affect our estimates. Insofar as institutional quality can influence regional disparities, this is likely to be largely due to the variation of institutional quality across regions (see Rodríguez-Pose, 2010 and references therein). In other words, income differences across regions are likely to be partly due to interregional institutional quality differences. Our measures of government quality capture perceptions of government efficiency across each country, at the local, regional and national levels. They do not reflect inter-regional differences in government quality and, as result, there is no reason to expect government quality, as we measure the concept here, to affect regional disparities. Notwithstanding this discussion, we have repeated our regressions with lagged values of our regional disparities indicators with no substantial change in our findings ${ }^{14}$.

Conceptually, reverse causality is a greater problem in relation to ethnic segregation. Alesina and Zhuravaskaya (2011) argue that in countries with low government quality, ethnic groups may live together to provide local public goods which the central government is unable to provide. More importantly for our sample of countries, the index of ethnic segregation depends on internal administrative boundaries which are at government's discretion. Fortunately, these authors generate an instrument for ethnic segregation which relates the spatial distribution of ethnic groups in a country to the composition of major ethnic groups present in neighbouring countries. The

\footnotetext{
${ }^{14}$ Instrumental variable techniques come up against the problem of the unavailability of suitable instruments for regional disparities (see Murray, 2006 for a discussion of the conditions that should be satisfied by good instruments).
} 
assumption is that people belonging to a particular group "gravitate" towards the borders of countries that are populated by people from the same group. When we employ this instrument and estimate via two stage least squares our results are maintained.

\section{Conclusion}

Previous scholars have explored the link between geography and institutional quality focusing on the importance of climatic conditions, population densities, mortality rates due to local diseases, the abundance of natural resources or transport costs. In this paper we turn our attention to another geographic variable namely, regional disparities. We hypothesize that greater regional disparities lead to more intense redistributive conflict over the territorial distribution of resources. Redistributive conflict tends to be a more attractive option for elected officials than improvements in government quality, because of the existence of organized interests groups opposed to public sector reforms. Higher regional disparities increase the salience of redistributive politics and tilt the balance of politics towards redistributive concerns and away from policies aimed at improving government quality. In other words, regional disparities-cum redistributive conflict crowd-out good government.

Our empirical analysis drawn from a sample of 22 OECD countries over the period from 1996 to 2006 provides strong support for our basic intuition. Moreover, we confirm the role of political decentralization and ethnic and linguistic segregation as amplifiers of the negative impact of regional inequalities on government quality. Both decentralization and segregation tend to heighten inter-regional redistributive conflict due to regional disparities, and ultimately undermine efficient government. Alternatively, we find that the negative impact of regional income differences can be mitigated by appropriate institutional design. Specifically, the presence of power sharing or shared rule whereby central and sub-central governments jointly decide policies at the national level tends to abate conflict to the benefit of good government. 
Table 3. Regional Disparities and Government Quality: The influence of political decentralization, ethno-linguistic segregation and shared rule. Feasible GLS (FGLS).

\begin{tabular}{|c|c|c|c|c|c|c|c|c|c|}
\hline \multirow[b]{2}{*}{$\begin{array}{l}\text { Regional Disparities } \\
\text { interacted with } \Rightarrow>\end{array}$} & \multirow{2}{*}{$\begin{array}{c}1) \\
\text { Political } \\
\text { Decentralization } 1\end{array}$} & \multirow{2}{*}{$\begin{array}{c}\text { (2) } \\
\text { Political } \\
\text { Decentralization } 2\end{array}$} & \multirow{2}{*}{$\begin{array}{c}(3) \\
\text { Ethnic } \\
\text { Segregation }\end{array}$} & \multirow{2}{*}{$\begin{array}{c}4) \\
\text { Language } \\
\text { Segregation }\end{array}$} & \multicolumn{5}{|c|}{ Shared Rule } \\
\hline & & & & & $\begin{array}{c}\text { (5) } \\
\text { Aggregate } \\
\text { Indicator }\end{array}$ & $\begin{array}{c}(6) \\
\text { Law Making }\end{array}$ & $\begin{array}{c}(7) \\
\text { Executive } \\
\text { Control } \\
\end{array}$ & $\begin{array}{c}\text { (8) } \\
\text { Fiscal Control }\end{array}$ & $\begin{array}{c}\text { (9) } \\
\text { Constitutiona } \\
\text { Reform }\end{array}$ \\
\hline GDP per capita & $\begin{array}{c}0.694 \\
(0.071)^{* * *}\end{array}$ & $\begin{array}{c}0.361 \\
(0.093)^{* \star *}\end{array}$ & $\begin{array}{c}0.520 \\
(0.081)^{* * *}\end{array}$ & $\begin{array}{c}0.602 \\
(0.074)^{* * *}\end{array}$ & $\begin{array}{c}0.383 \\
(0.116)^{\star * *}\end{array}$ & $\begin{array}{c}0.395 \\
(0.119)^{* * *}\end{array}$ & $\begin{array}{c}0.317 \\
(0.094)^{\star \star \star}\end{array}$ & $\begin{array}{c}0.326 \\
(0.104)^{* * *}\end{array}$ & $\begin{array}{c}0.347 \\
(0.106)^{* * *}\end{array}$ \\
\hline Size of Government & $\begin{array}{l}0.813 \\
(0,138)^{* * *}\end{array}$ & $\begin{array}{l}0.298 \\
(0,156)^{*}\end{array}$ & $\begin{array}{l}0.649 \\
(0,145)^{* * *}\end{array}$ & $\begin{array}{l}0.795 \\
(0,165)^{* * *}\end{array}$ & $\begin{array}{l}0.457 \\
(0,178)^{* \star}\end{array}$ & $\begin{array}{l}0.527 \\
(0,201)^{* * *}\end{array}$ & $\begin{array}{l}0.358 \\
(0,147)^{* \star}\end{array}$ & $\begin{array}{c}0.489 \\
(0,172)^{\star \star *}\end{array}$ & $\begin{array}{l}0.492 \\
(0,165)^{\star \star}\end{array}$ \\
\hline Fiscal Decentralization & $\begin{array}{c}0.589 \\
(0,161)^{* * *}\end{array}$ & $\begin{array}{c}0.526 \\
(0,148)^{\star * *}\end{array}$ & $\begin{array}{l}0.627 \\
(0,158)^{* * *}\end{array}$ & $\begin{array}{c}0.528 \\
(0,144)^{* \star *}\end{array}$ & $\begin{array}{c}0.561 \\
(0,172)^{* * * *}\end{array}$ & $\begin{array}{c}0.576 \\
(0,186)^{* \star *}\end{array}$ & $\begin{array}{l}0.657 \\
(0,151)^{* * *}\end{array}$ & $\begin{array}{c}0.619 \\
(0,175)^{* \star *}\end{array}$ & $\begin{array}{c}0.648 \\
(0,174)^{\star \star \star *}\end{array}$ \\
\hline Transition Economies & $\begin{array}{l}-0.278 \\
(0,123)^{* \star}\end{array}$ & $\begin{array}{l}-0.527 \\
(0,156)^{\star \star *}\end{array}$ & $\begin{array}{l}-0.482 \\
(0,136)^{* \star *}\end{array}$ & $\begin{array}{c}-0.541 \\
(0,134)^{\star * *}\end{array}$ & $\begin{array}{c}-0.478 \\
(0,157)^{\star * *}\end{array}$ & $\begin{array}{c}-0.383 \\
(0,145)^{* * *}\end{array}$ & $\begin{array}{l}-0.637 \\
(0,144)^{* \star *}\end{array}$ & $\begin{array}{c}-0.527 \\
(0,149)^{\star * *}\end{array}$ & $\begin{array}{c}-0.490 \\
(0,143)^{\star * *}\end{array}$ \\
\hline Political Decentralization & $\begin{array}{l}0.025 \\
(0,263)\end{array}$ & $\begin{array}{l}0.262 \\
(0,070)\end{array}$ & $\begin{array}{l}-0.309 \\
(0,184)^{*}\end{array}$ & $\begin{array}{l}-0.256 \\
(0,205)\end{array}$ & $\begin{array}{l}-0.261 \\
(0,177)\end{array}$ & $\begin{array}{l}-0.321 \\
(0,162)^{* *}\end{array}$ & $\begin{array}{l}-0.226 \\
(0,188)\end{array}$ & $\begin{array}{l}-0.253 \\
(0,183)\end{array}$ & $\begin{array}{c}-0.313 \\
(0,175)^{*}\end{array}$ \\
\hline Ethnic Segregation & $\begin{array}{l}-0.572 \\
(0.577)\end{array}$ & $\begin{array}{l}-0.050 \\
(0.704)\end{array}$ & $\begin{array}{c}2.243 \\
(0.983)^{* *}\end{array}$ & & $\begin{array}{l}-0.021 \\
(0.602)\end{array}$ & $\begin{array}{l}-0.437 \\
(0.576)\end{array}$ & $\begin{array}{l}0.011 \\
(0.606)\end{array}$ & $\begin{array}{l}-0.179 \\
(0.602)\end{array}$ & $\begin{array}{l}0.143 \\
(0.557)\end{array}$ \\
\hline Language Segregation & & & & $\begin{array}{l}2.426 \\
(0.940)^{* *}\end{array}$ & & & & & \\
\hline Share Rule & & & & & $\begin{array}{l}-0.032 \\
(0.020)\end{array}$ & $\begin{array}{l}-0.093 \\
(0.077)\end{array}$ & $\begin{array}{l}-0.115 \\
(0.080)\end{array}$ & $\begin{array}{l}-0.044 \\
(0.041)\end{array}$ & $\begin{array}{l}-0.061 \\
(0.047)\end{array}$ \\
\hline Regional Disparities & $\begin{array}{l}-0.025 \\
(0.554)\end{array}$ & $\begin{array}{l}0.350 \\
(0.360)\end{array}$ & $\begin{array}{l}-0.472 \\
(0.238)^{* *}\end{array}$ & $\begin{array}{l}-0.209 \\
(0.203)\end{array}$ & $\begin{array}{l}-1.106 \\
(0.339)^{\star * *}\end{array}$ & $\begin{array}{l}-1.449 \\
(0.344)^{\star * \star}\end{array}$ & $\begin{array}{l}-0.635 \\
(0.231)^{* \star *}\end{array}$ & $\begin{array}{c}-0.931 \\
(0.275)^{\star * *}\end{array}$ & $\begin{array}{l}-1.013 \\
(0.174)^{* * *}\end{array}$ \\
\hline $\begin{array}{l}\text { Regional Disparities * } \\
\text { Political Decentralization }\end{array}$ & $\begin{array}{l}-1.466 \\
(0.211)^{\star * *}\end{array}$ & $\begin{array}{l}-0.648 \\
(0.248)^{* * *}\end{array}$ & & & & & & & \\
\hline $\begin{array}{l}\text { Regional Disparities * } \\
\text { Segregation }\end{array}$ & & & $\begin{array}{l}-10.254 \\
(2.645)^{* * *}\end{array}$ & $\begin{array}{l}-14.243 \\
(2.459)^{\star * *}\end{array}$ & & & & & \\
\hline $\begin{array}{l}\text { Regional Disparities * } \\
\text { Shared Rule }\end{array}$ & & & & & $\begin{array}{l}0.151 \\
(0.080)^{*}\end{array}$ & $\begin{array}{l}0.630 \\
(0.258)^{* *}\end{array}$ & $\begin{array}{l}0.340 \\
(0.202)^{*}\end{array}$ & $\begin{array}{l}0.310 \\
(0.144)^{* *}\end{array}$ & $\begin{array}{l}0.357 \\
(0.169)^{\star \star}\end{array}$ \\
\hline Adjusted $\mathrm{R}^{2}$ & 0.61 & 0.39 & 0.63 & 0.66 & 0.49 & 0.53 & 0.46 & 0.46 & 0.48 \\
\hline Number of Countries & 22 & 23 & 22 & 18 & 21 & 21 & 21 & 21 & 21 \\
\hline Observations & 212 & 220 & 212 & 172 & 207 & 207 & 207 & 207 & 207 \\
\hline
\end{tabular}

Standard Errors in parentheses. ****** measures statistical significance at the 10,5 and $1 \%$ levels respectively. Government quality is measured by way of the World Governance Indicators and regional disparities using PW-CV. Political Decentralization 1 is from Schneider (2003) and 2 is STATE from the DPI. Aggregate indicator is the average of the four dimension of shared rule shown. "Political Decentralization 1" and "Ethnic and Language segregation" are time constant variables. All regressions report FGLS using Period SUR weights. 


\section{Bibliography}

Acemoglu, D., Johnson, S., Robinson, J. A. (2001) The colonial origins of comparative development: an empirical investigation. American Economic Review, 91: 13691401.

Acemoglu, D., Johnson, S., Robinson, J. A. (2002) Reversal of fortune: geography and institutions in the making of the modern world income distribution. Quarterly Journal of Economics, 117: 1231-1294.

Acemoglu, D., Johnson, S., Robinson, J. A. (2005) Institutions as a fundamental cause of long-run growth. In P. Aghion and S. N. Durlauf (eds) Handbook of economic growth, pp. 385-472. Amsterdam: Elsevier.

Ades, A., Di Tella, R. (1999) Rents, competition and corruption. American Economic Review, 89(4): 982-993.

Alesina, A., Spolaore, E. (1997) On the Number and Size of Nations. Quarterly Journal of Economics, 112 (4): 1027-1056.

Alesina, A., Spolaore, E. (2003). The size of nations. Cambridge MA, London: MIT Press.

Alesina, A., Zhuravskaya, E. (2011) Segregation and the quality of government in a cross-section of countries. American Economic Review, 101(5): 1872-1911.

Bakke, K., Wibbels, E. (2006) Diversity, disparity, and civil conflict in federal states, World Politics, 59(1): 1-50.

Banerjee, A., Rohini, P. (2007) Parochial politics: ethnic preferences and politician corruption. CEPR Discussion Papers 6381.

Bardhan, P. (2002) Decentralization of governance and development. Journal of Economic Perspectives 16 (4), 185-205.

Barro, R. (2000) Inequality and growth in a panel of countries. Journal of Economic Growth, 5(1): 5-32.

Beck, T., Clarke, G., Groff, A., Keefer, P., Walsh, P. (2001) New tools in comparative political economy: the database of political institutions. World Bank Economic Review, 15(1) 165 - 176.

Brancati, D. (2006) Decentralization: fueling the fire or dampening the flames of ethnic conflict and secessionism. International Organization 60: 651-685.

Brancati, D. (2007) The origins and strengths of regional parties. British Journal of Political Science, 38: 135-159.

Bolton P., Roland G. (1997) The breakup of nations: a political economy analysis. Quarterly of Economics, 112 (4): 1057-1090.

Brennan G., Buchanan J. (1980) The power to tax. Analytical foundations of a fiscal constitution. Cambridge: Cambridge University Press.

Brown, G. (2009) Spatial disparity, regional authority, and ethnic protest in contemporary democracies: A panel data analysis, 1985-2003. Ethnopolitics 8:1.

Buchanan, J. and Congleton, R. (1998): Politics by principal not interest. Towards nondiscriminatory democracy, Cambridge University Press.

Buchanan, J., Faith, R. (1987) Secession and the limits of taxation: Toward a theory of internal exit. American Economic Review, 77: 1023-31.

Engerman, S., Sokoloff, K. (1997) Factor endowments, institutions, and differential paths of growth among new world economies: a view from economic historians of the United States. In Stephen Haber, Ed. How Latin America Fell Behind: 
Essays on the Economic Histories of Brazil and Mexico. Stanford University Press.

Engerman, S., Sokoloff, K. (2002) Factor endowments, inequality, and paths of development among New World economies. Economia, 1: 41-88.

Enikolopov, R., Zhuravskaya, E. (2007) Decentralization and political institutions. Journal of Public Economics, 91(11-12): 2261-2290.

Fan., S, Lin, C., Treisman, D. (2009) Political decentralization and corruption: evidence from around the world. Journal of Public Economics, 93: 14 - 34.

Fisman R., Gatti R. (2002). Decentralization and corruption: evidence across countries. Journal of Public Economics, 83: 325 - 345.

Glaeser, E. (2005) The political economy of hatred. Quarterly Journal of Economics, 120(1): 45-86.

Hardin, R. (1995) One for all. The logic of group conflict. Princeton, New Jersey: Princeton University Press.

Hooghe, L. (2004) Belgium: hollowing the center. In Federalism and Territorial Cleavages, edited by U. Amoretti and N. Bermeo. Baltimore: The Johns Hopkins University Press.

Hooghe, L., Schakel, A. Marks, G. (2008) Appendix B: country and regional scores. Regional and Federal Studies, 18(2): 259-274.

Hsiao, C. (2003) Analysis of panel data. 2nd edition. Cambridge University Press.

Islam, R., Montenegro, C. (2002) What determines the quality of institutions. Background paper for the World Development Report 2002: Building Institutions for Markets.

Kyriacou, A. (2000) An ethnically based federal and bicameral system: the case of Cyprus. International Review of Law and Economics 20(2): 251-268.

Kyriacou, A. (2005) Rationality, ethnicity and institutions: a survey of issues and results. Journal of Economic Surveys, 19(1): 23-42.

Kyriacou, A. (2009) Decision rules, membership and political centralization in the European Union. European Journal of Law and Economics, 27(2): 143-158.

Kyriacou, A., Roca-Sagalés, O. (2011a). Fiscal and political decentralization and government quality. Environment and Planning C (Government and Policy), 29(2): 204-223.

Kyriacou, A., Roca-Sagalés, O. (2011b). Fiscal decentralization and government quality in the OECD. Economics Letters 111(3): 191-193.

Langbein, L., Knack, S. (2010). The worldwide world governance indicators: six, one, or none? Journal of Development Studies 46(2) 350-370.

La Porta, R., Lopez-de-Silanes, F., Shleifer, A., Vishny, R., (1999) The quality of government. Journal of Law, Economics and Organization, 15(1) $222-279$.

Lecours, A., Daniel, B. (2010) Federalism and fiscal policy: the politics of equalization in Canada. Publius 40(4): 569-596.

Leite, C., Wiedemann, J. (2002) Does mother nature corrupt? Natural resources, corruption and economic growth. In G. Abed and S. Gupta, Editors, Governance, corruption, and economic performance. Washington, DC: IMF, pp. 159-196.

Lessmann, C. (2009) Fiscal decentralization and regional disparity: evidence from cross section and panel data. Environment and Planning A, 41 2455-73.

Lijphart, A. (1984) Democracies: patterns of majoritarian and consensus government in twenty-one countries. New Haven: Yale University Press. 
McKinnon, R. (1997) Market-preserving fiscal federalism in the American monetary union. In Macroeconomic dimensions of public finance: essays in honour of Vito Tanzi Eds M, Blejer,T Ter-Minassian (Routledge, London), pp 73-93.

Meltzer, A., Richard, S. (1981) A rational theory of the size of government. Journal of Political Economy, 89: 914-27.

Miquel, G. (2007).The control of politicians in divided societies: the politics of fear. Review of Economic Studies, 74, 1259-1274.

Montinola, G., Jackman, R. (2002) Sources of corruption: a cross-country study. British Journal of Political Science, 32: 147-170.

Murray, M. (2006) Avoiding invalid instruments and coping with weak instruments. Journal of Economic Perspectives, 20(4) 111 - 132.

Navia, P., Velasco, A. (2003) The politics of second generation reforms in Latin America. In: P. Kuczynski and J. Williamson, editors. After the Washington consensus: restarting growth and reform in Latin America. Washington, DC: Institute for International Economics.

Oates, W. (1972) Fiscal federalism. (Harcourt Brace Jovanovich, New York)

Østby, G., Ragnhild, N., Rød, J. (2009) Regional inequalities and civil conflict in SubSaharan Africa. International Studies Quarterly, 53(2): 301-324.

Panizza, U. (2001) Electoral rules, political systems and institutional quality. Economics and Politics, 13(3) $311-342$

Parks, R. (1967) Efficient estimation of a system of regression equations when disturbances are both serially and contemporaneously correlated. Journal of the American Statistical Association, 62: 500-09

Persson, T., Tabellini, G. (1996). Federal fiscal constitutions: risk sharing and redistribution. Journal of Political Economy, 104(5): 979-1009.

Petrakos, G. (2001) Patterns of regional inequality in transition economies. European Planning Studies, 9: 359-383.

Prud'homme, R. (1995) On the dangers of decentralization. World Bank Research Observer, 10(2), 201-220.

Qian Y., Weingast B., (1997) Federalism as a commitment to preserving market incentives Journal of Economic Perspectives, 11 83-92.

Rodden, J. (2004) Comparative federalism and decentralization. On meaning and measurement. Comparative Politics, 36(4): 481-500.

Rodden, J. (2009) Federalism and interregional redistribution. Mimeo: Department of Political Science, Stanford University.

Rodríguez-Pose, A. (2010) Do institutions matter for regional development in the EU? Imdea Working Paper series in Economics and Social Sciences 2010/2, Madrid.

Rodríguez-Pose, A., Ezcurra R, (2010) Does decentralization matter for regional disparities? A cross-country analysis. Journal of Economic Geography, 110 61944.

Rodrik, D. (1996) Understanding economic policy reform. Journal of Economic Literature 34(1): 9-41.

Rodrik, D., Subramanian, F., Trebbi, F. (2004) Institutions rule: the primacy of institutions over geography and integration in economic development. Journal of Economic Growth, Vol. 9: 131-65.

Sambanis, N., Branko M. (2009) Explaining the demand for sovereignty. Mimeo: Yale University Press. 
Sokoloff, K., Engerman, S. (2000) History lessons: institutions, factor endowments, and paths of development in the New World. Journal of Economic Perspectives, 14: 217-232.

Sorens, J. (2005) The cross-sectional determinants of secessionism in advanced democracies. Comparative Political Studies, 38, 304.

Sorens, J. (2008) Regionalists against secession: the political economy of territory in advanced democracies. Nationalism and Ethnic Politics 14: 325-360.

Stevenson, G. (2007) Fiscal federalism and the burden of history. In Fiscal Federalism and the Future of Canada, Conference Proceedings, Sept 28-29, 06 - Folio 6. Kingston, Ontario: Queens University Institute of Intergovernmental Relations.

Stewart, F. (2002) Horizontal inequalities: a neglected dimension of development. CRISE Working Paper No. 81. Oxford: Queen Elizabeth House.

Stewart, F. (2008) Editor. Horizontal inequalities and conflict. Understanding group violence in multiethnic societies. London: Palgrave.

Tanzi, V. (1998) Corruption around the world. Causes, consequences, scope, and cures. IMF Staff Papers 45, 559-594.

Tommasi, M., Velasco, A. (1996) Where are we in the political economy of reform? Journal of Economic Policy Reform, 1: 187-238.

Treisman, T. (1996) The politics of intergovernmental transfers in post-soviet Russia. British Journal of Political Science, 26: 299-335.

Treisman, D. (1998) Fiscal redistribution in a fragile federation: Moscow and the regions in 1994. British Journal of Political Science, 28(1): 185-222. 1998.

Treisman, D. (2000) The causes of corruption: a cross-national study. Journal of Public Economics, 76: 399-457.

Treisman, D. (2002) Decentralization and the quality of government. Mimeo: University of California.

Van Rijckeghem, C., Weder, B. (2001) Bureaucratic corruption and the rate of temptation: do wages in the civil service affect corruption, and by how much? Journal of Development Economics, 65(2): 307-331.

Wei, S. (2000) Natural openness and good government. NBER Working Paper 7765.

Wibbels, E. (2005) Decentralized governance, constitution formation, and redistribution. Constitutional Political Economy, 16(2): 161-188.

Wintrobe, R. (1995) Some economics of ethnic capital formation and conflict. In A, Breton., G, Galeotti., P, Salmon., R, Wintrobe. (eds.) Nationalism and rationality (pp. 43-70). Cambridge University Press.

Wooldridge, J. (2006) Introductory econometrics. A modern approach. (Thompson South-Western). 


\section{Appendix 1. List of Countries}

Australia, Austria, Belgium, Canada, Czech Republic, Denmark, Finland, France, Germany, Hungary, Ireland, Italy, Mexico, Netherlands, Norway, Portugal, Slovak Republic, Spain, Sweden, Switzerland, United Kingdom, and United States.

\section{Appendix 2. Data Sources}

\begin{tabular}{|c|c|c|}
\hline Variable & Source & Comments \\
\hline World Governance Indicators & World Bank & $\begin{array}{l}\text { Time varying } \\
\text { (annual) }\end{array}$ \\
\hline International Country Risk Guide & Political Risk Services Group & $\begin{array}{l}\text { Time varying } \\
\text { (annual) }\end{array}$ \\
\hline Regional GDP per capita & $\begin{array}{l}\text { Cambridge Econometrics and national } \\
\text { statistics (courtesy of A. Rodríguez-Pose) }\end{array}$ & $\begin{array}{l}\text { Time varying } \\
\text { (annual) }\end{array}$ \\
\hline PW-CV-UNEMP & Eurostat Regional Yearbook 2010 & $\begin{array}{l}\text { Time varying } \\
\text { (annual) }\end{array}$ \\
\hline Population & $\begin{array}{l}\text { World Development Indicators (World } \\
\text { Bank) }\end{array}$ & $\begin{array}{l}\text { Time varying } \\
\text { (annual) }\end{array}$ \\
\hline Political decentralization 1 & Schneider (2003) & Time invariant \\
\hline Political decentralization 2 & Database of Political Institutions & $\begin{array}{l}\text { Time varying } \\
\text { (annual) }\end{array}$ \\
\hline Ethnic and language segregation & Alesina and Zhuravskaya (2011) & Time invariant \\
\hline Shared rule & Hooghe et al (2008) & $\begin{array}{l}\text { Time varying } \\
\text { (annual) }\end{array}$ \\
\hline GDP per capita & Penn Tables & $\begin{array}{l}\text { Time varying } \\
\text { (annual) }\end{array}$ \\
\hline Government size & IMF Government Finance Statistics & $\begin{array}{l}\text { Time varying } \\
\text { (annual) }\end{array}$ \\
\hline Fiscal decentralization & $\begin{array}{l}\text { OECD General Government Accounts } \\
\text { (courtesy of I. Sanz) }\end{array}$ & $\begin{array}{l}\text { Time varying } \\
\text { (annual) }\end{array}$ \\
\hline Transition economies & La Porta et al (1999) & Time invariant \\
\hline
\end{tabular}

Notes: See main text for the definitions of the variables. 